\title{
KAJIAN FEMINITAS PUTRI HARISBAYA DALAM WAWACAN BABAD SUMEDANG KARYA ABDUR'ROCHMAN
}

\author{
Anna Meirlina Sulianti ${ }^{1}$, Widyasari ${ }^{2}$ \\ 1. SMA 1 Negeri Sumedang \\ 2. FHISIP Universitas Terbuka \\ e-mail: annameirlinasulianti@gmail.com $^{1}$ dan wiwid@ecampus.ut.ac.id²
}

\begin{tabular}{|c|c|}
\hline Article Info & \multirow[b]{2}{*}{$\begin{array}{l}\text { Abstract } \\
\text { The study aimed to (1) find out "citra" or image of Princess Harisbaya } \\
\text { in the Sundanese classical poetry Wawacan Babad Sumedang written } \\
\text { by Abdur'rochman; (2) find out how Princess Harisbaya represents } \\
\text { feminism in Wawacan Babad Sumedang. The research was an } \\
\text { analytical description. The study used the qualitative method. Literary } \\
\text { and documentation studies on Wawacan Babad Sumedang were } \\
\text { conducted to gain the data. The steps of collecting data were reading } \\
\text { texts accurately, making notes of relevant data, identifying and } \\
\text { classifying the data, and making data tabulation and description. In } \\
\text { analyzing the structure, AJ Greimas theory was adopted. The result of } \\
\text { the study showed that Wawacan Babad Sumedang depicts citra and } \\
\text { habits of Princess Harisbaya and her stories. }\end{array}$} \\
\hline $\begin{array}{l}\text { Keywords: } \\
\text { Wawacan } \\
\text { Citra; } \\
\text { Femininity. }\end{array}$ & \\
\hline Article Info & Abstrak \\
\hline $\begin{array}{l}\text { Kata Kunci: } \\
\text { Wawacan } \\
\text { Citra; } \\
\text { Femininity. }\end{array}$ & $\begin{array}{l}\text { Penelitian ini bertujuan untuk (1) mengetahui citra Putri Harisbaya } \\
\text { dalam puisi klasik Sunda Wawacan Babad Sumedang karya } \\
\text { Abdur'raochman; (2) Mengetahui kajian feminitas Putri Harisbaya } \\
\text { dalam Wawacan Babad Sumedang karya Abdur'raochman. Penelitian } \\
\text { ini merupakan penelitian deskriptif analitis. Penelitian ini } \\
\text { menggunakan dan menerapkan prinsip-prinsip metodologi kualitatif. } \\
\text { Untuk memperoleh data tersebut dilakukan studi literatur dan } \\
\text { dokumentasi tentang Wawacan Babad Sumedang. Langkah-langkah } \\
\text { pengumpulan data adalah membaca teks secara akurat, mencatat data } \\
\text { yang relevan, mengidentifikasi, dan mengklasifikasikan data, } \\
\text { membuat tabulasi dan deskripsi data. Dalam menganalisis struktur } \\
\text { digunakan teori AJ Greimas. Hasil penelitian menunjukkan bahwa } \\
\text { Wawacan Babad Sumedang menggambarkan citra dan kebiasaan Putri } \\
\text { Harisbaya dan cerita-ceritanya. }\end{array}$ \\
\hline
\end{tabular}

\section{Pendahuluan}

Perempuan identik dengan kecantikan. Beberapa legenda dunia menggambarkan kecantikan wanita yang akhirnya memicu masalah. Epos dunia tentang kecantikan Helen dari Troya menyebabkan peperangan di antara dua kerajaan. Kisah dari Negeri Tiongkok tentang Xi Shi salah satu wanita tercantik yang dikirim sebagai upeti oleh Raja negeri Yue, Gou Jian Yang untuk Fuchai, pangeran negeri Wu karena negaranya ditaklukkan oleh negara Wu. Di Indonesia, Di dalam Kitab Pararaton, kecantikan Ken Dedes menarik hati Tunggul Ametung sehingga melarikan gadis itu untuk dijadikan istri. Ken Arok, pengawalnya, jatuh hati dan membunuh Tunggul Ametung untuk memiliki Ken Dedes dan menjadi raja di Singasari walau pada akhirnya ia mati di tangan anak Tunggul Ametung. Dalam Kidung Sunda diceritakan kisah tragis yang dialami Putri Dyahpitaloka atau Citraresmi dalam peristiwa Perang bubat. Konon lukisan wajahnya yang cantik jelita telah membuat 
Hayam Wuruk jatuh cinta dan melamarnya. Akibat perselisihan paham, Putri Dyahpitaloka yang melihat ayah dan anggota keluarga kerajaannya terbunuh menolak dijadikan upeti dan memilih bunuh diri demi mepertahankan harga diri serta martabat kerajaan Sunda. Jadi, di salah satu sisi kecantikan perempuan menyebabkan permasalahan terhadap kaum laki-laki, tetapi di sisi lain kecantikan itu juga dijadikan alat politik kaum laki-laki dalam budaya patriarki yang ada dalam masyarakat tempo dulu.

Jika melihat perkembangan historiografi tradisional dunia, Indonesia, dan Jawa Barat dapat dikatakan bahwa sejarah adalah milik kaum laki-laki. Tema-tema sentral dalam sejarah condong dengan sejarah politik dan militer yang berkaitan erat dengan masalah kekuasaan dan keperkasaan kaum laki-laki. Pada umumnya bersifat elitis, artinya membicarakan orang besar, kelompok penguasa, dan tidak memberi tempat bagi rakyat kecil. Karena itu, wanita hanya sedikit yang disebut. Itu pun hanya wanita kalangan atas. Wanita yang diceritakan di dalamnya tidak lain hanyalah tokoh figuran, tokoh isteri yang menempel pada suami atau anak lelakinya yang menjadi raja atau bupati. Nasib wanita diantaranya digambarkan ada yang bernasib baik, buruk, dialung boyong, dan dilecehkan. Hingga abad ke-19, data historis menyiratkan bahwa wanita adalah objek bukan subjek. Wanita adalah "benda" yang bisa dijadikan upeti, dihadiahkan, dijadikan alat politik, bahkan dipinjamkan jika perlu.

\subsection{Wawacan Babad}

Wawacan Babad Sumedang merupakan karya historiografi tradisional yang berasal dari daerah Sumedang dan ditulis bahkan disalin sekitar abad 17-20. Hal ini berdasarkan temuan penulis bahwa Wawacan Babad Sumedang memakai jenis huruf, yaitu huruf Jawi (di Musium Leiden Belanda), huruf Arab Pegon (di Musium Pangeran Geusan Ulun Sumedang dan milik pribadi masyarakat Sumedang), dan huruf Latin (di Perpusnas RI). Wawacan Babad Sumedang sebagai naskah babad mempunyai sifat ganda, yakni sebagai karya sejarah dan karya sastra. Atau dikategorikan sastra sejarah.

Sebagai karya sejarah, Wawacan Babad Sumedang karya Abdurrochan yang berada di Perpusnas RI ini mengandung silsilah Pangeran Geusan Ulun dengan istrinya, Nyi Mas Gedeng Waru; Pangeran Girilaya, dengan isterinya, Putri Harisbaya. Juga mengungkapkan "Peristiwa Harisbaya" yang menimbulkan konflik antara tokoh Pangeran Geusan Ulun, raja Sumedang Larang (1580-1601), dengan Pangeran Girilaya dari kerajaan Cirebon karena melarikan istrinya yang bernama Putri Harisbaya dengan bantuan empat pengawal kepercayaan Pangeran Geusan Ulun bernama Sanghyang Hawu/Jaya Perkosa, Wirajaya (Nangganan), Pancar Buana/Terong Peot, dan Kondang Hapa hingga membuat geger. Menurut Pustaka Kertabhumi I /2 (1694: 70), kejadian penculikan Putri Harisbaya, isteri Pangeran Girilaya Cirebon itu terjadi tahun 1585 Masehi. Pada akhirnya Pangeran Geusan Ulun menikah dengan Putri Harisbaya dua tahun kemudian, yaitu tanggal 2 bagian terang bulan Waisaka tahun 1509 Saka atau 10 April 1587 Masehi.

Wawacan adalah cerita panjang yang digubah menurut bentuk pupuh, bentuk ini merupakan pengaruh dari kesusastraan Jawa, melalui kaum bangsawan dan alim ulama yaitu kira-kira pada pertengahan abad ke-17 M (Rosidi, 1966: 11 - 12). Jika yang dimaksud oleh batasan itu cerita sama dengan naratif atau teks yang mengandung 3 unsur pokok satuan naratif yakni tokoh, alur, dan latar yang memiliki sifat koherensi dalam khazanah naskah Sunda banyak yang menggunakan peristilahan wawacan namun tidak mengacu ke batasan itu. Pada bahasan ini akan menggunakan istilah wawacan seperti apa adanya yang terdapat pada khazanah naskah Sunda, yaitu teks yang digubah dalam bentuk pupuh yang di dalamnya berisi deskripsi yang mengedepankan lebih dari satu situasi (lebih panjang dari guguritan). Adapun babad adalah kisahan berbahasa Jawa, Sunda, Bali, Sasak, dan Madura yg berisi peristiwa sejarah; cerita sejarah; riwayat; sejarah; tambo (KBBI:2005).

Wawacan dalam khazanah kesusastraan Sunda telah melalui kurun waktu kurang lebih tiga setengah abad. Salah satu perkembangan dari wawacan dalam rentang waktu panjang itu adalah pencantuman nama pengarang dalam gubahannya. Pada periode awal lahirnya sampai abad ke-19 M, 
wawacan-wawacan ditulis orang tanpa nama pengarang (anonim). Selanjutnya muncul tradisi pencantuman nama pengarang pada gubahannya.

\subsection{Citra Wanita dalam Sejarah Sunda}

Historiografi tradisional diartikan sebagai tulisan sejarah yang dibuat berdasarkan tradisi yang sudah berlangsung berabad-abad dan ditulis oleh para pujangga, para empu, atau penulis-penulis khusus yang ada di istana-istana atau kabupaten-kabupaten. Di Tatar Sunda, historiografi tradisional ini dikenal dengan sebutan wawacan, babad, sejarah, serat, carita, dan lain-lain. Masalah citra wanita dalam sejarah Sunda masa lalu berkaitan dengan dua hal, yaitu sebagai berikut:

1) Masalah seks dan gender. Hal-hal yang menyangkut masalah seks adalah penampilan fisik yang membedakan wanita dari pria secara kodrati, sedangkan masalah gender adalah masalah sosiobudaya, dalam hal ini wanita dilekati oleh simbol-simbol feminin, seperti lemah-lembut, keibuan, cantik, dan emosional; sebaliknya laki-laki dilekati oleh simbol maskulin, seperti kuat, perkasa, jantan, dan rasional. Dilihat dari perbedaan simbolis ini muncul anggapan bahwa wanita lebih lemah daripada pria.

2) Masalah status sosial. Kita tahu, bahwa dalam stratifikasi sosial masyarakat Sunda dikenal tiga lapisan masyarakat, yaitu kaum menak (kelompok aristokrat) yang menempati lapisan paling atas, kaum santana yang berada di antara kaum menak dan lapisan paling rendah, serta kaum somah dan cacah yang berada pada lapisan paling rendah. Dengan demikian, ada wanita yang termasuk kaum bangsawan dengan segala hak istimewanya, dan ada pula wanita yang termasuk kaum somah yang harus menerima statusnya sebagai rakyat kecil. (Lubis, Nina Herlina:183)

\subsection{Feminisme dan Feminitas}

Untuk mengungkapkan citra perempuan dalam sastra, maka harus dihubungkan dengan perempuan sebagai pusat analisis. Dalam hal ini diperlukan pengetahuan dan pemaknaan mengenai konsep feminisme. Feminisme bisa dimakna dalam dua hal. Pertama, feminisme adalah suatu teori tentang persamaan antara laki-laki dan perempuan di bidang politik, ekonomi, dan sosial. Kedua, feminisme sebagai kegiatan terorganisasi atau gerakan yang memperjuangankan hak-hak serta kepentingan perempuan. Pengertian kedua lebih dikenal dengan istilah emansipasi.

Istilah feminisme muncul pada abad ke-17. Dipandang dari sudut sosial, menurut Selden (1996:139), feminisme muncul dari rasa ketidakpuasaan terhadap sistem Patriakrki yang ada pada masyarakat. Selden menggunakan istilah Patriarki untuk menguraikan sebab penindasan terhadap perempuan. Patriarki menentukan bahwa laki-laki itu superior dan menempatkan perempuan sebagai inferior.

Di dalam struktur masyarakat Indonesia, maskulinitas seorang lelaki digambarkan sebagai sosok rasional, kuat, subjek, memimpin, dominan, publik, superior, dan mengambil keputusan. Adapun feminitas seorang perempuan digambarkan sebagai sosok emosional, lemah, objek, dipimpin, subordinat, privat, inferior, dan mengikuti keputusan. Menurut Prabasmoro (2006:245) seorang bertubuh perempuan harus menunjukkan identitas feminin termasuk melakukan tugas-tugas atau pekerjaan yang dianggap/berada di ranah feminin. Demikian pula mereka yang bertubuh lakilaki harus menunjukkan identitas maskulin dan melakukan pekerjaan-pekerjaan yang dianggap maskulin dan/atau berada di ranah maskulin publik. Hal inilah yang membangun sebuah tatanan budaya yang patriarkal.

Kehidupan wanita sebelum lahirnya femininisme didominasi sistem patriarki yang ada dalam masyarakat. Perempuan walaupun seorang putri atau ratu sekalipun mengikuti aturan tersebut. Seorang putri bahkan tidak bisa memilih atau menolak calon suami yang disodorkan orang tuanya. Sumber sejarah menyebutkan bahwa Putri Harisbaya dijadikan upeti oleh Sultan Mataram atas kesetiaan Pangeran Cirebon kepadanya. Putri Harisbaya tidak bisa menolak perkawinan tersebut dan ia menjadi istri selir dari keturunan bangsawan di kerajaan Cirebon. Raja biasanya memiliki satu permaisuri dan berhak memiliki selir dari keturunan bangsawan atau pun rakyat jelata. 
Sandra Bartky (1997) mengatakan bahwa feminitas adalah praktik-praktik yang menghasilkan tubuh perempuan dalam sikap dan perilaku yang dianggap feminim. Tiga feminitas yang menentukan terbentuknya Identitas gender pada perempuan yaitu (1) tubuh ideal berdasarkan kurun waktu tertentu; (2) sikap atau tingkah laku, gestur tubuh, dan gerakan-gerakan yang dihasilkannya di dalam keseharian; (3) perempuan harus selalu berpenampilan cantik. Oleh sebab itu, feminitas menjadi seperangkat aturan yang mengatur perilaku dan penampilan perempuan. Aturan-aturan tersebut bertujuan agar perempuan memiliki daya pikat seksual seperti yang diinginkan oleh laki-laki. Perempuan harus menyesuaikan diri dengan definisi feminisme yang ideal tersebut.

Menurut Hollows (2000), feminitas adalah sebuah area teoretis yang mempresentasikan semua yang dimarginalkan dalam tatanan patriarkal dan dengan demikian merupakan sebuah istilah yang menggambarkan suatu posisi yang diduduki oleh subjek periferal. jadi, feminitas menuntut perempuan memiliki perilaku dan penampilan yang diharapkan sesuai tatanan dalam struktur masyarakat, seperti halnya Putri Harisbaya sebagai seorang wanita bangsawan.

Naskah-naskah kuno di Jawa barat sedikit sekali mencatat feminitas atau perilaku perempuan. Cerita mitos mencatat Sunan Ambu, Nyi Pohaci atau Dewi Sri dan lain-lain. Adapun naskah-naskah kuno yang bersifat sejarah seperti Kitab, sajarah, atau babad hanya ada beberapa wanita sekelas bangsawan yang tercatat di dalamnya. Salah satunya dalam tradisi wawacan babad, ada tokoh wanita yaitu Putri Harisbaya yang diceritakan memicu peperangan antara Kerajaan Sumedang Larang dan Kerajaan Cirebon pada abad ke-14.

\section{Metode Penelitian}

Metode penelitian yang digunakan adalah metode deskriptif kualitatif, yaitu metode penelitian yang pelaksanaannya tidak hanya mengumpulkan data saja, melainkan meliputi analisis dan interpretasi tentang arti data itu dan masalah yang diungkap merupakan sesuatu yang ada dan terjadi saat ini. Teknik pengumpulan data yang dilakukan meliputi: (1) Studi kepustakaan, yaitu kegiatan membaca berbagai buku, majalah, koran, internet yang ada kaitannya dengan masalah yang akan diteliti: (2) Pengumpulan data, yaitu kegiatan mengadakan observasi dan pengamatan langsung pada naskah yang akan diteliti. Adapun teknik analisis data yang dilakukan meliputi (1) penginventarisasian, (2) pengelompokkan data, (3) penelitian data, yaitu menganalisis data yang diperoleh, dan (4) penarikan kesimpulan berdasarkan hasil analisis.

\section{Pembahasan}

\section{Citra atau Gender dan Status Putri Harisbaya Menurut Wawacan Babad Sumedang}

Wawacan Babad Sumedang memiliki versi pula, yaitu terdiri dua versi cerita (Abdurachman, 1986: 42-43). Cerita versi A yang penulis gunakan, yaitu dari perpustakaan nasional RI yang awalnya disimpan di Musium Nasional Jakarta dengan No. kode: Plt. 29 berasal dari koleksi C.M. Pleyte. Naskah dengan tulisan tangan tersebut berjudul Wawacan Babad Sumedang (Abdur'rachman, 1907). Penulis menganggap cerita versi A merupakan hipogram dari cerita versi B. Berikut data identitas naskah Wawacan Babad Sumedang sebagai berikut:

\begin{tabular}{|l|}
\hline Tempat: di perpustakaan nasional RI, Jakarta \\
\hline Judul: Wawacan Babad Sumedang \\
\hline Lokasi: lantai 3 Perpusnas RI koleksi C.M. Pleyte \\
\hline Asal naskah: koleksi C. M. Pleyte peti 121 \\
\hline Ukuran: 21,7 x 16,5 cm \\
\hline Tebal naskah: 52 halaman 24 baris/halaman \\
\hline Huruf: latin \\
\hline Bahasa: Sunda ejaan Van Ophyusen \\
\hline Bentuk karangan: puisi (tembang) \\
\hline
\end{tabular}


Penulis: Naskah ini ditulis atau disalin Abdur'rocman pada tanggal 17 Dzulkaidah $1324 \mathrm{H}$ (tanggal 2 Januari 1907) dan selesai ditulis hari Jumat tanggal 26 bulan Hapit (Djulhijah) 1324 Hijriah (tanggal 9 Februari 1907). ia menyalin berdasarkan paririmbon milik orang-orang tua berbahasa Jawa Jawi.

Babad Sumedang ini memiliki bagian-bagian urutan yaitu, (1) pengantar: doa, harapan, dll.; (2) pendahuluan: silsilah; (3) isi pokok; dan (4) penutup. BSM memiliki bagian-bagian urutan yaitu sebagai berikut ini.

1) Pengantar berupa pembukaaan kisah yang mengemukakan bentuk karangan yaitu puisi/tembang, objek karangan yaitu cerita/sejarah tentang daerah Sumedang masa lampau, dan sumber karangan yaitu sumber tradisional yaitu buku primbon berbahasa jawa kawi yang dimiliki pemiliknya.

\section{Pupuh Asmarandana Bait 1-4}

1. Sim kuring mimiti nulis, nuju tanggal tujuh welas, Dulkaidah bulanna teh, sarta dina dinten arba, ninggang kana hurupna, hijrah Kanjeng Nabi Rosul, sarebu aya punjulna.

2. Tilu ratus punjul deui, punjul dua puluh opat, sareng taunna taun He, sim kuring ka sadayana,nyuhunkeun dihampura, reh kuring mangun catur, nyarios Babad Sumedang.

3. Carios nu rek digurit, upami kaginuluran, nukil tina paririmbon, sepuh-sepuh nu kagungan, ieu sugan henteu salah, catur kusut pabaliut, wantuning Sunda salinan.

4. Tina basa Jawa kawi rea nu teu kahartosna, estu boboloncokan bae, ngagurit nyasat mapara, manawi kaleresan, tinaptu rea nu luput, awit bubuka carita.

\section{Terjemahan}

1. Saya awal menulis, pada tanggal tujuh belas, Dzulkaidah bulannya, serta di hari Rabu, jatuh pada aksaranya, hijrah Nabi Rosul, seribu ada bulannya.

2. Tiga ratus lebih lagi, lebih dua puluh empat, dan tahunnya tahun $\mathrm{He}$, saya kepada semua, meminta maaf, karena saya mengarang cerita, bercerita tentang Babad Sumedang

3. Cerita yang akan ditembangkan, seumpama diturut, meniru dari primbon, orang tua yang memiliki (primbon), ini semoga tidak salah, cerita kusut simpang siur, karena bahasa Sunda salinan.

4. Dari bahasa Jawa Kawi yang banyak tak dimengerti, sungguh luka berdarah-darah saja, mengarang tembang tak menjadi kebaikan apapun, barangkali kebetulan benar, tentu banyak yang salah, dimulai membuka cerita.

2) Pendahuluan berisi silsilah Pangeran Girilaya dan Pangeran Geusan Ulun, asal-usul Putri Harisbaya, dan asal-usul Ny Mas Gedang Cukangwaru

a. Silsilah Leluhur diawali kanjeng Sunan Gunung Jati yang menjadi leluhur Pangeran Girilaya (bait 5 - 14) dan Pangeran Geusan Ulun (bait 11 - 12)

\section{Pupuh Asmarandana Bait 5}

5. Kanjeng Sunan Gunung Jati, kagungan sahiji putra, pameget segut moncorong, kakasihna putra Sunan, Pangeran Pasarean, ku panjang anu dicatur, Pangeran putrana dua.

\section{Terjemahan}

5. Kanjeng Sunan Gunung Jati, memiliki satu putra, anak laki-laki yang semangat bersinar, nama putra Sunan, Pangeran Pasarean, karena panjang yang akan diceritakan, Pangeran memiliki dua putra. 
Karya sastra Wawacan Babad Sumedang sangat menarik karena mengandung silsilah tokoh. Bagan silsilah Pangeran Geusan Ulun dan Pangeran Girilaya dari pihak ayah merupakan keturunan dari Sunan Gunung Jati yaitu sebagai berikut.

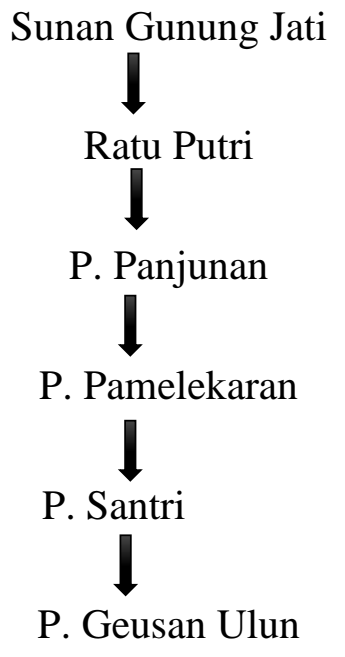

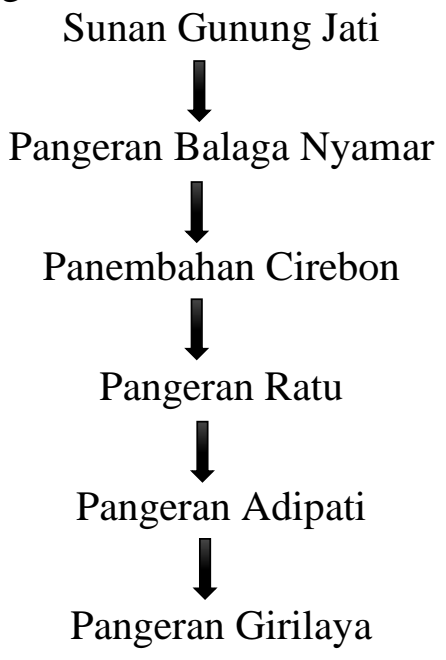

b. asal-usul Putri Harisbaya (bait 8 - 10)

\section{Pupuh Asmarandana Bait 8}

8. Yaitu Pangeran Adipati, sudah memiliki putra juga, Sang Pangeran adipatos, yaitu Pangeran Girilaya, Raja Negara Cirebon, Girilaya raja yang unggul, istrinya Putri Mataram.

9. Turunan bangsawan yang berpengaruh, namanya ratu Harisbaya, ...

c. asal-usul Ny Mas Gedang Cukangwaru (bait 13-14)

\section{Pupuh Sinom Bait 14}

14. Kakasihna Raja Putri, garwa Gesan-Ulun tea, katelahna Nyimas Gedeng, wantuning jaman baheula, carang Raden teu Agan, Nyimas Gedeng Cukangwaru, karuhun menak Sumedang.

\section{Terjemahan}

8. Yaitu Pangeran Adipati, sudah memiliki putra juga, Sang Pangeran adipatos, yaitu Pangeran Girilaya, Raja Negara Cirebon, Girilaya raja yang unggul, istrinya Putri Mataram.

9. Turunan bangsawan yang berpengaruh, namanya ratu Harisbaya,

\section{Terjemahan}

14. Namanya Raja putri, istri Geusan Ulun itu, disebut Nyimas gedeng, lantaran zaman dahulu, jarang Raden juga Agan, Nyi Mas Gedeng Cukangwaru, nenek moyang bangsawan Sumedang.

d. Isi pokok: Kisah Pangeran Girilaya, Pangeran Geusan Ulun, dan Putri Harisbaya (bait 15-211)

\section{Pupuh Asmarandana Bait 15}

15. Ratu Kutamaya Nagri, kacarios hij mangsa, medal ti jero Kadaton, kersana angkat ka Demak, sareng gandek nu kocap, nami embah Sayang Hawu. senapati kapetengan.

\section{Terjemahan}

15. Ratu Negeri Kutamaya, diceritakan suatu hari, keluar dari dalam keraton, hendak berangkat ke Demak, bersama punakawan yang disebut, bernama Embah Sayang hawu, Senapati pengawal raja. 


\section{Pupuh Asmarandana Bait 211}

211.Sabab masih reuneuh leutik, ari lamun geus babar, ditikah taya sawios, nu kapanggih ku raka, ieu carios taya, anu kocap ngan sakitu, tuladana geus tamat.

\section{Terjemahan}

211.Sebab masih hamil kecil, kalau sudah lahir dinikah tak apa, yang ditemukan oleh kakak, ini cerita, hanya sampai di sini, sudah selesai.

e. Dalam penutup diungkapkan mengenai selesainya karangan ini.

\section{Pupuh Asmarandana Bait 212}

212.Tamatna ieu ditulis, dina malem juma'ah pisan, sartana teh juma'ah Pon, ping dua puluh genepna, bulan Hapit nu lumampah, Hijrah Nabi Rasul, tilu ratus dua puluh opat.

\section{Terjemahan}

212.Tamat ditulis, di malam jumat, di hari jumat pon dua puluh enam bulan hapit berlangsung, hijrah Nabi Rasul, tiga ratus dua puluh empat.

Wawacan Babad Sumedang ini merupakan puisi pupuh. Setiap pupuh memiliki watak pupuh. Pupuh yang digunakan dalam Wawacan Babad Sumedang diawali dan diakhiri pupuh asmarandana. Wawacan Babad Sumedang menggunakan 8 jenis pupuh, yaitu asmarandana, sinom, kinanti, mijil, pangkur, durma, magatru, dan pucung. Pengulangan pupuh terjadi pada dua pupuh, yaitu asmarandana dan pangkur.

Berikut tabel jenis pupuh yang ada di dalam Wawacan Babad Sumedang sebagai berikut:

\begin{tabular}{|l|c|l|}
\hline JENIS PUPUH & (BAIT KE-) & \multicolumn{1}{|c|}{ WATAK PUPUH } \\
\hline Asmarandana & $(1-20) ;$ & saling menyayangi \\
\hline Sinom & $(21-54) ;$ & kegembiraan \\
\hline Kinanti & $(55-77) ;$ & prihatin, was-was \\
\hline Mijil & $(78-89) ;$ & susah, bingung, nelangsa, nyeri, menangis, meratap \\
\hline Pangkur & $(90-108) ;$ & nafsu, siap perang \\
\hline Durma & $(109-127) ;$ & marah, perang \\
\hline Magatru & $(128-144) ;$ & $\begin{array}{l}\text { Mengalami keprihatinan, kadang untuk guyon, pengisi } \\
\text { waktu }\end{array}$ \\
\hline Pangkur & $(145-164) ;$ & nafsu, siap perang \\
\hline Pucung & $(165-182) ;$ & Kaget, sadar, bercanda, berisi nasihat, pemberitahuan \\
\hline Asmarandana & $(183-212)$ & saling menyayangi \\
\hline
\end{tabular}

Wawawan tergolong puisi klasik bersifat epos. Ada cerita di dalamnya. Terkadang wawacan disusun dalam beratus-ratus bait sehingga dibukukan. Karena termasuk epos dan bersifat naratif, maka kita dapat menemukan fakta cerita di dalamnya yaitu tokoh, alur, dan latar. Berikut ini skema aktan yang menggambarkan tokoh dan penokohan Putri Harisbaya dalam Wawacan Babad Sumedang: 
Skema Aktan tokoh Putri Harisbaya Wawacan Babad Sumedang

PENGIRIM

Jatuh cinta dan ingin memiliki

Pangeran Geusan Ulun

PENOLONG $\longrightarrow$

- Jaya Perkosa meminta Pangeran Geusan Ulun membalas cubitan Putri Harisbaya

- Kandaga Lante dan Bala Tentara Sumedang Larang

- Sultan Mataram

\section{Kontruksi Feminitas Putri Harisbaya dalam Naskah Wawavan Babad Sumedang}

Adapun pokok bahasan mengenai citra dan feminitas Putri Harisbaya dalam Wawacan Babad Sumedang berupa (1) identitas dan status sosial; (2) sikap atau tingkah laku, gestur tubuh, dan gerakan-gerakan yang dihasilkannya di dalam keseharian yaitu sebagai berikut:

A. Identitas Putri Harisbaya sebagai putri Mataram

Dalam naskah babad Sumedang, dijelaskan Raja Cirebon yang bernama Girilaya memiliki istri yang berasal dari Mataram bernama Putri Harisbaya. Identitas Putri Harisbaya dikatakan putri Mataram yang memiliki tedak arya ba'adji berarti termasuk golongan bangsawan yang memiliki nilai tinggi, memiliki pengetahuan, turunan para raja Mataram, dan sangat dihargai.

1) .... Girilaya Ratu punjul, garwana Putri Mataram. Tedak Arya yang ba'adji, nami Ratu Harisbaya, Putri ngalih ka cirebon..... (B 8-9)

Girilaya raja unggul, istrinya putri Mataram, turunan bangsawan yang sakti, namanya Ratu Harisbaya, Putri pindah ke cirebon.....)

Selain itu juga identitas seorang putri atau bangsawan digambarkan cantik (geulis) yaitu, Nyi Mas Gedeng Cukangwaru, permaisuri dari Pangeran Geusan Ulun, raja Sumedang Larang. Nyi Mas Gedeng Cukangwaru merupakan putri Sunda asli yang dianggap nenek moyang para bangsawan Sumedang.

2) Garwana putri tur geulis .... katelahna Nyimas Gedeng, wantuning jaman baheula, carang Raden teu Agan, Nyimas Gedeng Cukangwaru, karuhun menak Sumedang. (B. 13-14) Istrinya seorang putri dan cantik, ... disebut Nyimas gedeng, lantaran zaman dahulu, jarang Raden juga Agan, Nyi Mas Gedeng Cukangwaru, nenek moyang bangsawan Sumedang.

B. Putri Harisbaya menjalankan tugas sebagai istri seorang raja:

Ketika Pangeran Geusan Ulun berkunjung ke Cirebon sepulang dari Demak, Pangeran Girilaya mempertemukan Putri Harisbaya dengan adik sepupunya, Pangeran Geusan Ulun. Pangeran Girilaya juga memerintahkan putri Harisbaya untuk menjamu (suguhan) serta melayani (masak dadakan) tamu kerajaan.

1) ...Girilaya nyaur Ratu Harisbaya. Rai! Rai! Harisbaya, ieu aya rai sumping, Ratu Nagri Kutamaya, enggal suguhan keur yayi, Harisbaya ningali, ka pangeran geusan ulun, teras linggih jeung raka, henteu lami Raja Putri, pok nimbalan olah bade ngahormatan. Tagiur masak dadakan, rencang sangu sareng cai, enggalna sor pamasangan, tuang leueut rakarai, mun ayeuna mah Patih, ditimbalan ku Jeng Ratu, tetebah pangkuleman, di jero masigit leutik, ... (B. 23-25) 
Girilaya memanggil Ratu Harisbaya. Dinda! Dinda! Harisbaya, ini ada adik datang. Ratu Negeri Kutamaya, cepat dijamu untuk adik, Harisbaya melihat, pada Pangeran Geusan Ulun, kemudian duduk dengan kakak, tak lama Raja Putri, berkata menyuruh menyiapkan jamuan sebagai penghormatan. Sibuk memasak dadakan, teman nasi dan air, cepatnya segera dihidangkan, makan minum kakak-adik, kalau sekarang disebut Patih, diperintah oleh Ratu, bebenah tempat tidur, di dalam masjid kecil, ...

Pangeran Girilaya pun memerintahkan agar Putri Harisbaya menghormati adik sepupunya itu, menjamunya, mengakui sebagai saudara sendiri, dan menyayangi seperti dirinya.

2) mangga hormat enya-enya, engkang mihape ka yayi, ulah kurang pasuguhan, yayi mangka eling-eling, ulah dipikapusing, dulur engkang Geusan Ulun. Yi, ulah asa-asa, sing midulur pet ku hinis, nya pangasih kudu sakumaha engkang. Pet dulur teges, baraya (B.31)

Silakan hormati baik-baik, kakak titip pada dinda, jangan kurang jejamuan, dinda harus ingat-ingat, jangan dibuat kesal, saudara kakak yaitu Geusan Ulun, dinda jangan ragu-ragu, harus merasa saudara sungguh, rasa sayang harus seperti yang kakak lakukan.

Putri Harisbaya memiliki tugas lain yaitu menyediakan wadah berisi wewangian dan mencipratkan wewangian pada semua tamu yang hadir. Pangeran Girilaya memiliki kebiasaan mengundang para ulama dan mempertemukan dengan tamu kerajaan. Sebagai tradisi setelah makan bersama, para tamu diciprati wewangian dari belakang oleh Putri Harisbaya.

3) ... Girilaya nimbalan garwa, aya Ratu ulah poho, ke sore bakal kumpul, barang dahar deui Pra'Alim, wanci pukul dalapan, dina pukul tujuh, yayi geus kudu sadia, sarta yayi kudu ganti cawis-cawis, boboreh seuseungitan. Dikepretan sakur anu hadir, saentosna wareg barang dahar, ti pungkurna ku boboreh .... (B. 38-39)

Girilaya menyuruh pada istri, hei, Ratu jangan lupa, nanti sore bakal kumpul makan lagi para ulama, waktu pukul 8, saat pukul 7, dinda sudah harus sedia, serta dinda harus ganti wadah persediaan, cairan wewangian. Dicipratkan pada semua yang hadir, setelah kenyang makan, dari belakang dengan cairan wewangian.

Sebagai istri, Putri Harisbaya turun tangan membantu melayani kegiatan makan bersama. Ia tidak tinggal diam melihat kesibukan yang ada dan tidak jumawa karena merasa sebagai turunan bangsawan, tetapi ikut serta dalam kegiatan kerajaan.

4) ... tata cirebon kitu, enggeus diambengkeun ku istri terkadang Harisbaya, ku anjeun nu ngurus, pabaliut ngaladenan .... (B. 41)

... tata cara Cirebon begitu, sudah dibawa oleh para wanita terkadang Harisbaya, dirinya sendiri ikut mengurusi, repot meladeni ...,

C. Putri Harisbaya jatuh cinta:

Permasalahan muncul, ketika Putri Harisbaya jatuh cinta dan tertarik dengan ketampanan Pangeran Geusan Ulun, sepupu suaminya itu dan bertekad untuk memilikinya. Hal tersebut tergambar pada isi bait berikut:

1) ...mun Geusan Ulun aji, antawis socana hurung, ngampura sok tejaan, Putri pun awas ningali, ngagebeg Putri duh Teja sulaksana. Tejana alus rupana, sulaksana anyar panggih... sabubarna tatamu Putri nalangsa. (B.27-28)

kalau Raja Geusan Ulun, antara dua matanya menyala, bersinar seperti berawan. Putri pun terus melihat, terperanjat Putri duh cahaya cemerlang yang terpuji... sepulangnya para tamu, putri merasa nelangsa.

2) ... nyaur lebeting galih, tambang ketan untun tipung, kumaha kalaksana, teja hayang kapimilik, huleng jentul Ratu Ayu Harisbaya. (B.29) 
... bicara di dalam hati, tambang ketan utun tipung (sampiran dari wawangsalan), bagaimana terlaksana, Teja ingin dimiliki, melamun Ratu Ayu Harisbaya.

3) Harisbaya meh saeutik deui, kalepasan manah jeung paningkah, goreng perdaya hareeng, asih campur jeung duyung, mun duyungna panarik iblis, asih ka piderekan, manis lain kitu, duyung bae anu aya, .... (B.45)

Harisbaya hampir sedikit lagi, hampir kelepasan hati dan perilakunya, jelek tipu daya, cinta bercampur tergila-gila, kalau tergila-gilanya adalah tarikan iblis, cinta pada saudara (sepupu), baik budi bukan begitu, tergila-gila saja yang ada, ....

D. Putri Harisbaya mencari jalan untuk menjalankan keinginannya:

Biasanya wanita digambarkan pasif dalam naskah-naskah kuno, tetapi berbeda dengan penggambaran tokoh Putri Harisbaya. Ia digambarkan tidak membiarkan dirinya hanya jatuh cinta begitu saja. Ia berniat melaksanakan keinginannya untuk memiliki Pangeran Geusan Ulun yang tampan. Kebetulan sekali Putri Harisbaya diperintahkan Pangeran Girilaya untuk menciprati tetamu dengan wewangian dari belakang dan ia menemukan cara untuk melaksanakan aksinya tersebut secara halus dan diam-diam.

1) Putri nyaur dina manah, aduh kabeneran teuing, aing bakal beunang jalan, samingkin moal katawis, eukeur mikir ti tadi, pijalananeun anu lembut,

Putri berkata dalam hati, aduh, kebetulan sekali, aku bakal mendapat jalan, semakin tak kentara, sedang berpikir dari tadi, jalan yang halus, ....

2) Putri tambah kawuwuh, jalan nu leutik sarta rikip, wangsul timbalan Raka, Harisbaya Ratu, nuhun timbalan kangraka, .... (B. 39)

Putri semakin menjadi-jadi, jalan kecil tapi halus, menjawab perintah kakak (suami), Ratu Harisbaya berkata, terima kasih perintah kakak, ....

Putri Harisbaya memenuhi perintah suaminya, Pangeran Girilaya dan pada saat menciprati Pangeran Geusan Ulun dari belakang dengan wewangian, ia mencubit sehingga Pangeran Geusan Ulun kaget dengan perbuatan kakak ipar sepupunya itu. Hal itu dilakukan berkali-kali. Pangeran Geusan Ulun pun menceritakan hal tersebut pada Eyang Jaya Perkosa, salah satu pengawalnya. Jaya Perkosa atau Sayang Hawu mengatakan bahwa sepertinya Putri Harisbaya menyukai Pangeran Geusan Ulun dan mengusulkan untuk membalas balik mencubit. Awalnya, Pangeran Geusan Ulun ragu, tetapi akhirnya ia memberanikan diri membalas mencubit.

3) ... Harisbaya eling ka timbalan, gapiuk nyandak boboreh, dikepretan ti pungkur, sadayana sakur nu hadir, hiji-hiji dihanca, lebah Geusan Ulun ngepretan langkung kacida, buni-buni ngepretan barina nyiwit, Geusan Ulun ngarenjag. (B. 42)

Harisbaya ingat pada perintah, cepat diambil cairan wewangian, dicipratkan dari belakang, semua yang hadir, satu persatu tak terlewat, kepada Geusan Ulun, menciprat lebih banyak, diam-diam menciprati sambil mencubit, Geusan Ulun terperanjat.

4) ... Nyi Ratu Harisbaya,ngepretan ti pungkur, ku boboreh seuseungitan, saban-saban lebah Geusan Ulun Raja, ngepret jeung nyiwit pisan. (B. 48)

Nyi ratu harisbaya, memercik dari belakang, dengan cairan wewangian, tiap-tiap bagian Raja Geusan Ulun, memercik sekaligus mencubit lagi.

5) Harisbaya geus ngaboborehan deui, ... Sang Pangeran taki-taki, harita mah newak pisan, diciwit deui Nyi Putri, ku Sang Ratu Kutamaya, Raja Putri lega galih. (B. 54-55)

... Harisbaya telah memercik lagi, .... Sang pangeran siap-siap, ketika itu sigap menangkap, dicubit kembali Nyi Putri, oleh Sang Ratu Kutamaya, Raja Putri hatinya lega. 
E. Putri Harisbaya diam-diam menemui Pangeran Geusan Ulun

Setelah Pangeran Geusan Ulun membalas cubitannya, Putri Harisbaya nekad memberanikan diri mendatangi tempat peristirahatan Pangeran Geusan Ulun dan pengawalnya pada malam hari dengan diam-diam.

1) Ratu Harisbaya lungsur, ka luar ti jero bumi, nyalira ka pondok semah, ngadigdig taya nu ngiring, keur bobot dua bulan, harita Nyi Ratu Putri. (B. 58)

Ratu Harisbaya turun, ke luar dari dalam rumah, sendiri ke pondok tamu, berjalan cepat tiada yang mengikuti, sedang hamil dua bulan, harita Nyi Ratu Putri.

2) Semuna susuruputan, Putri ngetrokan ti pipir .... Kaget Pangeran San-Ulun, reh nguping jalmi dipipir, ngetrokan haharewosan, ka gandek miwarang bijil, Sayang Hawu tras kaluar, tetela Nyi Ratu Putri. (B.59-60)

tampaknya pelan-pelan, Putri mengetuk dari samping .... Kaget Pangeran Geusan Ulun, saat mendengar orang di samping, mengetuk berbisik-bisik, pada punakawan menyuruh keluar, Sayang Hawu kemudian keluar, ternyata Nyi Ratu Putri.

Dalam percakapan dengan Geusan Ulun, Putri Harisbaya berkata lebih baik mati dan mau ikut serta dengan Pangeran geusan Ulun.

3) ... cing atuh kumaha kuring,teu kaduga lila-lila, nya weleh paeh pribadi, pikir kuring saenyana, rek waleh sieun teu jadi. (B. 65)

... coba harus bagaimana saya, tidak kuat lama-lama, lebih baik mati diri, pikir saya sebenarnya, mau jujur tapi takut tak jadi.

4) ... ikhlas raga reujeung pati, lantaran ti kahadean, kuring tangtos bela pati, awak kuring saenyana, lain palsuan sim kuring. (B. 68)

... ikhlas raga dan mati, karena dari kebaikan, saya tentu bela mati, badan saya sebetulnya, bukan palsu (bohong) diriku.

F. Putri Harisbaya rela ikut melarikan diri dengan Pangeran Geusan Ulun:

1) ... Putri bobot dua bulan, digandong jeung lumpat tarik, wayahna bae da suka, dibelaan bijil getih. (B.77)

Putri sedang hamil dua bulan, digendong dan dibawa lari cepat, oleh karena suka, dilakukan walau keluar darah.

2) Harisbaya bijil ti Nagri, ku aki digandong, geus anggang mah Putri angkat bae, turut jalan angkat ti peuting ... (B. 78)

Harisbaya keluarnya dari negeri, oleh aki digendong, agak jauh putri berjalan. Berjalan tengah malam,

3) kocap di Cirebon, sadayana kaleungitan gehger. sumawona Mantri di Nagri, istri-istri nangis, reh leungiteun Ratu. (B.79)

dikisahkan di Cirebon, semua kehilangan geger, terutama Mantri di negeri, perempuanperempuan menangis, karena kehilangan Ratu (Harisbaya).

G. Putri Harisbaya pergi ke pasar dan memeriksa harga dagangan

Setelah di Sumedang, Putri Harisbaya ikut berkeliling memeriksa pasar Sumedang. Ketika ditanya pedagang ikan yang menyamar dari kerajaan Cirebon, ia menjawab berasal dari Cirebon.

1) ... kacarios Kangjeng Ratu, kersa ngaronda pasar, sareng garwa nu anom medal kadaton, bareng sumpingna ka pasar, Geusan Ulun Ratu Putri. Ningali sakur dagangan, tur mariksa hargana sahiji-hiji, sareng palebah nu nyamur, ningal dagangan peda, mariksakeun hargana Jawa ngawangsul sahiji harga sauang, ngalengis Nyi Ratu Putri. ... Ki Sodager tumaros ka garwa Ratu, ti mana bumi gamparan, ti Cirebon lahir Putri. (B. 93-94) 
diceritakan Kangjeng Ratu, akan meronda pasar, bersama istri nu anom keluar keraton, bersama datangnya ke pasar, Geusan Ulun dan Ratu Putri. Melihat setiap dagangan, kemudian memeriksa harganya satu-satu, ketika di bagian yang menyamar, melihat dagangan ikan peda, memeriksa harganya, orang Jawa menjawab satu buah seharga seuang, Nelangsa Nyi Ratu Putri... Ki Saudagar bertanya pada istri Ratu, dari mana asalnya, dari cirebon jawab Putri.

H. Penyelesaian kasus Putri Harisbaya

Pangeran Girilaya berusaha mencari dan merebut kembali Putri Harisbaya. Ia memerintahkan dua abdi menyamar untuk menjadi pedagang ke Sumedang sehingga keberadaan Putri Harisbaya dapat diketahui di kerajaan Sumedanglarang. Akhirnya, Pangeran Girilaya mengirimkan pasukan ke Sumedang dan mengajak berperang.

1) Kudu nitah dua jalma ka Sumedang teh nyidikeun pri hal Putri, enya atawa teu puguh, aya di Kutamaya, ... nimbalan kadua abdi. Sina api-api dagang, ka Sumedang jalma anu meunang milih gancangna utusan Tuluy, sarupa Jawa dagang .... (B. 91-92)

Harus menyuruh dua orang ke Sumedang menyelidiki perihal Putri, ada atau tidak jelas, ada di Kutamaya, ... menyuruh dua abdi. Disuruh pura-pura berdagang, ke Sumedang orang yang sudah terpilih segera pergi, serupa orang jawa berdagang ....

2) Kawentarkeun ka Nagara Kutamaya, lamun aya Prajurit, ti Cirebon Jawa, geus nieun Pasangrahan, Kanjeng Gesan-Ulun Aji, mariksa Embah, kumaha aku budi. Reh ayeuna bejana musuh geus datang, anu rek nyusul Nyai, Sayang-Hawu nyembah, Gusti ulah cangcaya, pun aki barani mati, bela ka Raja, moal sieun ngaberik. (B.110-111)

Telah diketahui ke negara Kutamaya, kalau ada prajurit, dari Cirebon Jawa, sudah membuat Pasanggrahan, Kanjeng Geusan Ulun Raja, memeriksa Embah, bagaimana yang harus diperbuat. Katanya sekarang musuh sudah datang, yang akan menyusul Nyai, Sayang Hawu menyembah, Tuan jangan tidak percaya, aki berani mati, bela pada Raja, tidak takut mengejar.

Karena kalah berperang, Pangeran Girilaya melaporkan persoalan Putri Harisbaya yang dilarikan Pangeran Geusan Ulun tersebut pada Sultan Mataram. Sultan Mataram memutuskan agar Pangeran Girilaya melepaskan Putri Harisbaya dan Pangeran Geusan Ulun membayar talak berupa penyerahan wilayah Majalengka sekarang. Putri Harisbaya dinikahi Pangeran Geusan Ulun setelah melahirkan Putra dari Pangeran Girilaya dan kelak putranya itu menjadi raja di Sumedang Larang bersama putra sulung dari Nyimas Gedeng karena Pangeran Geusan Ulun membagi dua kerajaannya.

3) Kagungan tilu tatali, cumantel ka Harisbaya, ayeuna dibeli bae, ku tanah sabeulah wetan, sareng saeusina tanah, ti Kulon wates Cilutung, Gunung Koromong ti wetan. Ti dinya diwangsul deui, seratna ku Girilaya, teu aya sawios-wios, narima geus ragrag talak, tilu sabab diiwat, nging wekas ka gesan Ulun, ulah waka rek ditikah. Sabab masih reuneuh leutik, ari lamun geus babar, ditikah taya sawios, nu kapanggih ku raka, ieu carios taya, anu kocap ngan sakitu, tuladana geus tamat (B. 209-211)

Mempunyai tiga hubungan, berkaitan dengan Harisbaya, ayeuna dibeli saja, oleh tanah sebelah Timur, dengan seisi tanah, dari barat berbatasan dengan Cilutung, Gunung Koromong dari Timur. Tak lama kemudian, suratnya oleh Girilaya, tidak apa-apa, menerima jatuhnya talak, sebab diculik, tapi berucap pada Geusan Ulun, jangan dulu dinikahi. Sebab masih hamil kecil, kalau sudah lahir dinikah tak apa, yang ditemukan oleh kakak, ini cerita, hanya sampai di sini, sudah selesai.

\section{Simpulan}

Putri Harisbaya pun diduga melakukan Lembangsari (menyeleweng) sesuatu yang tidak patut dilakukan seorang putri raja. Tentunya hal tersebut tidak sesuai dengan pakem yang menuntut perempuan memiliki perilaku dan penampilan yang diharapkan sesuai tatanan dalam struktur 
masyarakat patriarki. Citra dan feminitas Putri Harisbaya sebagai seorang wanita bangsawan yang tergambar dalam isi naskah Wawacan babad Sumedang sebagai berikut:

1) Citra Harisbaya secara seks dan gender digambarkan berpenampilan fisik wanita karena dipanggil nyai, putri, ratu putri, yang menunjukkan ciri khas panggilan wanita. Ia juga memiliki simbol-simbol feminin, sifat keibuan, sifat emosional dan ego yang tinggi.

2) Feminitas atau perilaku Putri Harisbaya digambarkan negatif dengan penggambaran perilaku Putri Harisbaya yang jatuh cinta dan ingin memiliki Pangeran Geusan Ulun, menggodanya secara halus. Ia pun berani datang ke tempat peristirahatan Pangeran Geusan Ulun, dan ia mengancam akan bunuh diri bila tidak diperkenankan ikut Pangeran Geusan Ulun. Pangeran Geusan Ulun tidak bisa menolaknya dan merencanakan pelarian di malam hari. Akibat pelarian dan penculikan tersebut, muncul peperangan kedua kerajaan. Putri Harisbaya harus ikut bersembunyi di tempat persembunyian, Dayeuh Luhur, yang berakibat kemarahan Jaya Perkosa karena wasiatnya perihal pohon hanjuang tidak dituruti, Pembunuhan Nangganan oleh Jaya Perkosa, dan sumpahnya berhenti mengabdi pada kerajaan Sumedanglarang. Pada akhirnya, Isi Surat Sultan Mataram menyelesaikan masalah antara dua kerajaan dan menyelesaikan kasus Putri Harisbaya.

\section{Daftar Pustaka}

Bartky, S.L. (1997). Foucault, Feminity, and the Moderzanition of patriarchal Power." Dalam Myers, Diana Tietjens (ed). Routledge: 93-111.

Ekadjati, Edi S. (1985). Naskah Sunda Lama Kelompok Babad. Jakarta: Pusat Pembinaan dan Pengembangan Bahasa.

Hollows, Joanne. (2010). Feminisme, Feminitas, dan Budaya Populer. Dialihbahasakan oleh Annisa Ismayasari. Yogyakarta: Jalasutra.

Lubis, Nina Herlina. (2000). Tradisi dan Transformasi Sejarah Sunda. Bandung: Humaniora utama Press.

Prabasmoro, Aquarini Priyatna. (2006). Kajian Budaya Feminis: Tubuh Sastra dan Budaya Pop. Bandung: Jalasutra.

Setyorini, Tantri. (2020). "Dua Belas Wanita tercantik dalam Legenda". Merdeka.com Surianingrat, Bayu. (1983). Sejarah Kabupaten I Bhumi Sumedang 1550 - 1950. T.t.: t.p. Suroso dkk. (2009). Kritik Sastra: Teori, Metodologi, dan Aplikasi. Yogyakarta: Elmatera Wangsakerta, P. (1694). Pustaka Nagara Kretabhumi, Parwa I Sarga 1 ,2, dan 3. Bogor: Transliterasi Saleh Danasasmita. 